\title{
Expression of genes controlling fat deposition in two genetically diverse beef cattle breeds fed high or low silage diets
}

Ana Sofia Henriques da Costa, Virgínia Maria Rico Pires, Carlos Mendes Godinho Andrade Fontes and José António Mestre Prates*

\begin{abstract}
Background: Both genetic background and finishing system can alter fat deposition, thus indicating their influence on adipogenic and lipogenic factors. However, the molecular mechanisms underlying fat deposition and fatty acid composition in beef cattle are not fully understood. This study aimed to assess the effect of breed and dietary silage level on the expression patterns of key genes controlling lipid metabolism in subcutaneous adipose tissue (SAT) and longissimus lumborum (LL) muscle of cattle. To that purpose, forty bulls from two genetically diverse Portuguese bovine breeds with distinct maturity rates, Alentejana and Barrosã, were selected and fed either low (30\% maize silage/70\% concentrate) or high silage (70\% maize silage/30\% concentrate) diets.

Results: The results suggested that enhanced deposition of fatty acids in the SAT from Barrosã bulls, when compared to Alentejana, could be due to higher expression levels of lipogenesis (SCD and $L P L$ ) and $\beta$-oxidation (CRAT) related genes. Our results also indicated that SREBF1 expression in the SAT is increased by feeding the low silage diet. Together, these results point out to a higher lipid turnover in the SAT of Barrosã bulls when compared to Alentejana. In turn, lipid deposition in the LL muscle is related to the expression of adipogenic (PPARG and FABP4) and lipogenic (ACACA and SCD) genes. The positive correlation between ACACA expression levels and total lipids, as well trans fatty acids, points to ACACA as a major player in intramuscular deposition in ruminants. Moreover, results reinforce the role of FABP4 in intramuscular fat development and the SAT as the major site for lipid metabolism in ruminants.
\end{abstract}

Conclusions: Overall, the results showed that SAT and LL muscle fatty acid composition are mostly dependent on the genetic background. In addition, dietary silage level impacted on muscle lipid metabolism to a greater extent than on that of SAT, as evaluated by gene expression levels of adipogenic and lipogenic factors. Moreover, the response to diet composition evaluated through mRNA levels and fatty acid composition showed interesting differences between Alentejana and Barrosã bulls. These findings provide evidence that the genetic background should be taken into account while devising diet-based strategies to manipulate fatty acid composition of beef cattle tissues.

Keywords: Beef cattle, Adipose tissue, Muscle, Gene expression, Fat deposition

\footnotetext{
* Correspondence: japrates@fmv.utl.pt

Secção de Bioquímica, CIISA, Faculdade de Medicina Veterinária,

Universidade Técnica de Lisboa, Av. da Universidade Técnica, Pólo

Universitário do Alto da Ajuda, Lisboa 1300-477, Portugal
} 


\section{Background}

During the last decades consumers have started demanding animal products of low fat and high polyunsaturated fatty acids content, while maintaining high and consistent quality $[1,2]$. To that purpose, research has been conducted on ruminant's adipogenesis and lipogenesis in order to improve both the production efficiency and beef quality. Adipose tissue is involved in the regulation of body homeostasis, particularly in energy metabolism, storage and expenditure. In cattle, fatty acid type and amount in muscles are directly associated with meat quality and its value. In fact, subcutaneous and intramuscular adipose tissues are the most important fat depots concerning meat quality traits. It is desirable that cattle carcasses have minimal amounts of fat stored in subcutaneous adipose tissue (SAT), without a detrimental decrease in intramuscular fat [3]. This can be achieved only if the regulation of lipid deposition in intramuscular and other fat depots differs substantially. Despite being the main site for de novo fatty acid and triacylglycerols (TAG) synthesis in ruminants [4], the SAT is also the most energetically inefficient fat depot and, therefore, considered an economic loss. However, while during the last decade knowledge of rodents and human fat physiology has progressed rapidly [5], the same information regarding ruminant species is very limited.

The expression level of adipogenic and lipogenic genes in adipose tissues is regulated by a number of transcription factors [6], whose differential expression is known to play a key role in lipid metabolism of cattle adipocytes [7]. Adipogenesis, lipogenesis, and lipolysis occur through the interaction of endogenous genetic mechanisms (mediated through gene expression and regulated by intrinsic factors), external controls (endocrine agents, extrinsic factors and nutritional metabolites), as well as local interactions within cells in a fat depot [8]. Despite the intricacies of lipogenesis and lipolysis, the role of some genes has been elucidated and confirmed to be related to fatty acid composition in cattle [6]. Potential regulatory mechanisms involved in the fatty acid deposition are lipogenic ( $A C A C A, L P L, F A B P 4$ and SCD) and oxidative (CPT1B and CRAT) genes, as well as transcription regulators (PPARA, PPARG and SREBF1). These genes have been described [9-11] for their roles and expression patterns during adipocyte differentiation, namely in studies comparing the regulation of adipose tissue deposition in distinct cattle breeds $[9,12]$.

Genetic factors underlying both the deposition and the turnover of individual fatty acids are not fully understood, although breed has been found to influence beef fatty acid composition [13]. Fatty acid composition in meat-producing animals is recognised to have implications on the nutritional and organoleptic properties of meat, as well as in its technological quality [14]. Ruminant products can be an additional source of the beneficial long-chain $n$-3 PUFA (EPA and DHA) for human diets [2] when the consumption of $n-3$ PUFA-rich foods, such as fish, is low. In addition, ruminant meats are major dietary sources of DPA (22:5n-3). Thus, genetic selection and breeding of animals with a desirable meat fatty composition may provide a source of beneficial fatty acids for human consumption [15]. Comparative differences of beef cattle present a unique resource to study several aspects of lipid metabolism. In addition to genetic factors, finishing systems can dramatically alter fat deposition [16], thus indicating that lipogenic activity is influenced by the dietary energy level, the energy source and, possibly, the forage to concentrate ratio. However, fatty acid composition in ruminant animals, unlike in monogastrics, is much less dependent on the diet, as a consequence of dietary fatty acid metabolism (i.e., isomerisation, biohydrogenation) within the rumen [17].

The biochemical processes and the molecular background affecting genetic variability of the complex trait of fat content and fatty acid composition are not yet fully understood, particularly with regard to European cattle breeds, because most of the recent studies have been performed on the specific genetic background of Japanese Black cattle [15]. Therefore, we conducted a trial with bulls from two Portuguese genetically diverse breeds [18] with distinct maturity rates, Alentejana and Barrosã, fed high or low silage diets. The working hypothesis of the present paper was that the expression of key genes controlling lipid metabolism during the finishing phase of cattle is breed-specific (Alentejana $v s$. Barrosã) and diet-modulated (high vs. low silage). Furthermore, given the distinct roles of subcutaneous and intramuscular fat depots in cattle lipid metabolism, the tissue-specific variations were also investigated through the analysis of both SAT and muscle gene expression patterns. Finally, the breed-, diet- and tissue-specific relationships among the expression level of these genes and fat content and composition were also assessed.

\section{Results}

Fatty acid composition of subcutaneous adipose tissue

Total lipid content and percentages of main fatty acids (i.e., those $>1 \%$ of total fatty acids and the main CLA isomer, 18:2c9t11) in the SAT from the four experimental groups are presented in Table 1 . The content of total lipids was higher $(P=0.002)$ in the SAT of Barrosã breed when compared to Alentejana bulls. Barrosã bulls had lower 14:0 $(P=0.024), 16: 0 \quad(P<0.001)$ and 18:0 $(P<0.001)$ fatty acid proportions in the SAT than the Alentejana bulls. Breed also determined the proportions of $16: 1 c 9, a-17: 0,18: 1 t 11,18: 1 c 9$ and 18:2c9t11-CLA 
Table 1 Total lipids and fatty acid composition of subcutaneous adipose tissue from Alentejana and Barrosã breeds fed either high or low silage-based diets ${ }^{1-3}$

\begin{tabular}{|c|c|c|c|c|c|c|c|c|c|c|c|}
\hline & \multicolumn{4}{|c|}{ Alentejana } & \multicolumn{4}{|c|}{ Barrosã } & \multicolumn{3}{|c|}{$P$} \\
\hline & \multicolumn{2}{|c|}{ HS } & \multicolumn{2}{|c|}{ LS } & \multicolumn{2}{|c|}{ HS } & \multicolumn{2}{|c|}{ LS } & \multirow[t]{2}{*}{ Breed } & \multirow[t]{2}{*}{ Diet } & \multirow[t]{2}{*}{ Breed $\times$ Die } \\
\hline & Mean & SE & Mean & SE & Mean & SE & Mean & SE & & & \\
\hline Total lipids & 58.44 & 1.748 & 59.67 & 1.063 & 63.89 & 1.729 & 65.17 & 1.689 & 0.002 & 0.434 & 0.987 \\
\hline \multicolumn{12}{|c|}{ Main individual fatty acids } \\
\hline $14: 0^{\S}$ & 3.50 & 0.198 & 3.52 & 0.189 & 2.98 & 0.130 & 3.23 & 0.164 & 0.024 & 0.426 & 0.517 \\
\hline $16: 0^{\S}$ & 27.24 & 0.429 & 26.57 & 0.552 & 23.63 & 0.444 & 25.11 & 0.659 & $<0.001$ & 0.449 & 0.051 \\
\hline $16: 1 c 9^{\S}$ & 4.03 & 0.380 & 3.83 & 0.242 & 4.89 & 0.263 & 5.41 & 0.248 & $<0.001$ & 0.590 & 0.218 \\
\hline$a-17: 0^{\S}$ & 1.30 & 0.026 & 1.13 & 0.031 & 1.45 & 0.035 & 1.35 & 0.038 & $<0.001$ & $<0.001$ & 0.315 \\
\hline $18: 0$ & 14.53 & 0.776 & 12.94 & 0.804 & 11.44 & 0.713 & 9.75 & 0.658 & $<0.001$ & 0.034 & 0.946 \\
\hline $18: 1 t 11$ & 1.41 & 0.123 & 1.36 & 0.129 & 1.88 & 0.125 & 1.74 & 0.113 & 0.002 & 0.456 & 0.705 \\
\hline $18: 1 c 9^{\S}$ & 33.5 & 1.019 & 34.65 & 0.835 & 37.43 & 0.752 & 37.18 & 0.872 & $<0.001$ & 0.610 & 0.431 \\
\hline 18:1c11 & 4.13 & 0.396 & 3.7 & 0.367 & 4.32 & 0.144 & 4.53 & 0.142 & 0.093 & 0.692 & 0.279 \\
\hline $\mathrm{CLA}(\mathrm{c} 9 t 11)$ & 0.40 & 0.034 & 0.34 & 0.026 & 0.80 & 0.041 & 0.81 & 0.041 & $<0.001$ & 0.504 & 0.324 \\
\hline $18: 2 n-6$ & $1.49^{b}$ & 0.030 & $2.29^{c}$ & 0.141 & $1.70^{\mathrm{a}}$ & 0.050 & $1.82^{\mathrm{a}}$ & 0.064 & 0.181 & $<0.001$ & 0.002 \\
\hline \multicolumn{12}{|l|}{ Partial sums } \\
\hline$\Sigma$ SFA & 46.89 & 1.000 & 44.76 & 1.303 & 39.61 & 1.035 & 39.21 & 1.184 & $<0.001$ & 0.273 & 0.453 \\
\hline$\Sigma$ MUFA & 44.89 & 1.034 & 46.00 & 1.323 & 50.62 & 1.092 & 51.54 & 1.223 & $<0.001$ & 0.395 & 0.933 \\
\hline$\Sigma$ TFA & 2.73 & 0.181 & 3.57 & 0.277 & 3.75 & 0.176 & 3.79 & 0.145 & 0.004 & 0.037 & 0.057 \\
\hline$\Sigma$ PUFA & $1.80^{\mathrm{a}}$ & 0.101 & $2.58^{\mathrm{c}}$ & 0.144 & $2.07^{b}$ & 0.055 & $2.11^{\mathrm{b}}$ & 0.067 & 0.347 & $<0.001$ & 0.001 \\
\hline$\sum n-3$ PUFA & $0.27^{\mathrm{a}}$ & 0.012 & $0.26^{\mathrm{a}}$ & 0.016 & $0.32^{b}$ & 0.008 & $0.25^{\mathrm{a}}$ & 0.005 & 0.081 & $<0.001$ & 0.012 \\
\hline$\sum n-6$ PUFA & $1.53^{\mathrm{a}}$ & 0.090 & $2.32^{c}$ & 0.134 & $1.75^{b}$ & 0.049 & $1.86^{\mathrm{b}}$ & 0.065 & 0.216 & $<0.001$ & 0.001 \\
\hline$\Sigma \mathrm{BCFA}$ & 2.69 & 0.085 & 2.06 & 0.051 & 2.77 & 0.068 & 2.25 & 0.060 & 0.051 & $<0.001$ & 0.411 \\
\hline
\end{tabular}

${ }^{1}$ Different superscripts differ at least $P<0.05$. SFA, sum of 12:0,14:0, 15:0, 16:0, 17:0, 18:0 and 20:0; MUFA, sum of 14:1c9, 16:1c7, 16:1c9, 17:1c9, 18:1c9, 18:1c11, 18:1c12, 18:1c13, 18:1c15, 19:1 and 20:1c11; TFA, sum of 18:1t6-t8, 18:1t9, 18:1t10, 18:1t11, 18:1t12, 18:1t16 + c14, 18:2c9t11 and 18:2t11c15; PUFA, sum of 18:2n-6, 18:3n-3, 20:3n-6 and 20:4n-6; BCFA, sum of $\mathrm{i}-14: 0, \mathrm{i}-15: 0$, a-15:0, i-16:0, i-17:0, a-17:0 and i-18:0.

${ }^{2}$ Total lipids are expressed as $\mathrm{g} / 100 \mathrm{~g}$ muscle; fatty acid composition is expressed as $\mathrm{g} / 100 \mathrm{~g}$ fatty acids.

${ }^{3} H S$, High silage; $L S$, Low silage.

${ }^{\S}$ Variable adjusted for total lipids.

fatty acids in the SAT, with the Barrosã breed having higher values when compared to the Alentejana bulls $(P<0.01)$. Trans fatty acids (TFA) were higher in Barrosã than in Alentejana bulls $(P=0.004)$. Diet influenced the proportions of $a-17: 0$ and 18:0 $(P<0.001$ and $P=0.034$, respectively), with the high silage fed bulls presenting the highest values. Animals fed the low silage diet had the highest proportions of TFA $(P=0.037)$. The branched chain fatty acids (BCFA), which are closely related to the rumen activity, were higher in animals fed the high silage diets $(P<0.001)$. A breed $\times$ diet interaction was found for the fatty acid 18:2n-6 $(P=0.002)$, with the Alentejana bulls fed the low silage diet presenting the highest proportion. While Alentejana bulls had higher proportions of saturated (SFA) but lower monounsaturated fatty acids (MUFA) percentages, the inverse pattern was observed in the Barrosã bulls $(P<0.001)$. Both total PUFA and $n-6$ PUFA percentages were higher in the Alentejana bulls fed the low silage diet, whereas in the SAT from Barrosã bulls no variation between diets was observed (breed $\times$ diet, $P=0.001$ ). The percentages of $n-3$ PUFA were the highest in the SAT from Barrosã bulls fed the high silage diet $(P=0.012)$.

\section{Fatty acid composition of muscle}

The values for total lipids and main fatty acids (i.e., those $>1 \%$ of total fatty acids and 18:2c9t11) in the muscle from the four experimental groups are presented in Table 2. Total lipid contents were higher in the muscle from Barrosã bulls fed the low silage diet in comparison to those fed the high silage diet, whereas no variation was observed for the Alentejana bulls (breed $\times$ diet, $P=0.001)$. The 14:0 proportion in the muscle was higher $(P<0.001)$ in the Barrosã breed when compared to the Alentejana bulls. Breed also influenced the percentages of 16:1c9,18:1c9 and 18:2c9t11-CLA in the muscle, with the Barrosã having higher values when compared to the Alentejana breed $(P<0.001)$. Barrosã bulls fed the low silage diet had $(P=0.037)$ the highest proportions of SFA. Both MUFA and TFA proportions were higher 
Table 2 Total lipids and fatty acid composition of longissimus lumborum muscle from Alentejana and Barrosã breeds fed either high or low silage diets ${ }^{1-3}$

\begin{tabular}{|c|c|c|c|c|c|c|c|c|c|c|c|}
\hline & \multicolumn{4}{|c|}{ Alentejana } & \multicolumn{4}{|c|}{ Barrosã } & \multicolumn{3}{|c|}{$P$} \\
\hline & \multicolumn{2}{|c|}{ HS } & \multicolumn{2}{|c|}{ LS } & \multicolumn{2}{|c|}{ HS } & \multicolumn{2}{|c|}{ LS } & \multirow[t]{2}{*}{ Breed } & \multirow[t]{2}{*}{ Diet } & \multirow[t]{2}{*}{ Breed $\times$ Diet } \\
\hline & Mean & SE & Mean & SE & Mean & SE & Mean & SE & & & \\
\hline Total lipids ${ }^{\S}$ & $1.21^{\mathrm{a}}$ & 0.758 & $1.25^{\mathrm{a}}$ & 0.836 & $1.76^{\mathrm{b}}$ & 1.208 & $2.76^{c}$ & 1.955 & $<0.001$ & $<0.001$ & 0.001 \\
\hline \multicolumn{12}{|c|}{ Main individual fatty acids } \\
\hline $14: 0^{\dagger}$ & 2.04 & 0.082 & 2.24 & 0.121 & 2.29 & 0.075 & 2.71 & 0.098 & $<0.001$ & 0.003 & 0.261 \\
\hline $16: 0^{+}$ & $23.50^{\mathrm{a}}$ & 0.362 & $23.17^{\mathrm{a}}$ & 0.439 & $23.33^{\mathrm{a}}$ & 0.325 & $25.40^{b}$ & 0.373 & 0.011 & 0.028 & 0.003 \\
\hline $16: 1 c 9$ & 2.37 & 0.162 & 2.52 & 0.102 & 2.85 & 0.103 & 3.27 & 0.189 & $<0.001$ & 0.057 & 0.361 \\
\hline $18: 0$ & 15.14 & 0.709 & 14.04 & 0.492 & 14.20 & 0.424 & 14.04 & 0.423 & 0.378 & 0.244 & 0.380 \\
\hline $18: 1 c 9^{\ddagger}$ & 28.36 & 0.702 & 28.85 & 0.783 & 31.04 & 0.823 & 33.52 & 0.645 & $<0.001$ & 0.053 & 0.189 \\
\hline $18: 1 c 11$ & 2.90 & 0.302 & 3.35 & 0.083 & 3.40 & 0.254 & 3.08 & 0.088 & 0.586 & 0.762 & 0.078 \\
\hline $\mathrm{CLA}(\mathrm{c} 9 t 11)$ & 0.21 & 0.011 & 0.20 & 0.014 & 0.45 & 0.025 & 0.45 & 0.018 & $<0.001$ & 0.815 & 0.789 \\
\hline $18: 2 n-6^{*}$ & $7.39^{c}$ & 0.387 & $8.32^{c}$ & 0.719 & $6.07^{b}$ & 0.329 & $4.22^{\mathrm{a}}$ & 0.251 & $<0.001$ & 0.333 & 0.007 \\
\hline $20: 4 n-6^{\dagger}$ & 2.39 & 0.156 & 2.25 & 0.148 & 1.53 & 0.140 & 1.28 & 0.117 & $<0.001$ & 0.001 & 0.052 \\
\hline \multicolumn{12}{|l|}{ Partial sums } \\
\hline$\Sigma \mathrm{SFA}^{\dagger}$ & $42.10^{a}$ & 0.755 & $40.69^{a}$ & 0.815 & $41.29^{a}$ & 0.672 & $43.22^{b}$ & 0.624 & 0.209 & 0.736 & 0.037 \\
\hline$\sum$ MUFA $^{\ddagger}$ & 35.77 & 0.876 & 36.92 & 0.866 & 41.58 & 0.825 & 40.31 & 0.939 & $<0.001$ & 0.952 & 0.206 \\
\hline$\Sigma$ TFA & 1.65 & 0.095 & 2.03 & 0.145 & 2.49 & 0.106 & 2.62 & 0.114 & $<0.001$ & 0.038 & 0.294 \\
\hline$\Sigma$ PUFA $^{*}$ & 11.92 & 0.465 & 12.57 & 0.929 & 9.11 & 0.959 & 7.29 & 0.491 & $<0.001$ & 0.446 & 0.111 \\
\hline$\sum n-3$ PUFA $^{+}$ & 1.50 & 0.095 & 1.13 & 0.059 & 1.23 & 0.134 & 0.661 & 0.038 & $<0.001$ & $<0.001$ & 0.288 \\
\hline$\sum n-6$ PUFA $^{*}$ & 10.27 & 0.407 & 11.34 & 0.886 & 7.90 & 0.791 & 6.55 & 0.472 & $<0.001$ & 0.843 & 0.083 \\
\hline$\Sigma$ BCFA & 1.66 & 0.062 & 1.41 & 0.057 & 1.71 & 0.054 & 1.46 & 0.054 & 0.394 & $<0.001$ & 0.956 \\
\hline
\end{tabular}

${ }^{5}$ Published in [19].

${ }^{1}$ Different superscripts differ at least $P<0.05$. SFA, sum of 12:0, 14:0, 15:0, 16:0, 17:0, 18:0, 20:0 and 21:0; MUFA, sum of $c 9-14: 1, c 7-16: 1, c 9-16: 1, c 9-17: 1, c 9-18: 1$, c11-18:1, c12-18:1, c13-18:1, 18:1c15 and c11-20:1; TFA, sum of 18:1t6-t8, 18:1t9, 18:1t10, 18:1t11, 18:1 t16 + c14 and 18:c9t11; PUFA, sum of 18:2n-6, 18:3n-6, 18:3n-3, 20:2n-6, 20:3n-6, 20:3n-9, 20:4n-6, 20:5n-3, 22:4n-6, 22:5n-3 and 22:6n-3; BCFA, sum of $i-15: 0, a-15: 0, i-16: 0, i-17: 0, a-17: 0$ and $i-18: 0$.

${ }^{2}$ Total lipids are expressed as $\mathrm{g} / 100 \mathrm{~g}$ muscle; fatty acid composition is expressed as $\mathrm{g} / 100 \mathrm{~g}$ fatty acids.

${ }^{3} H S$ high silage, $L S$ low silage.

${ }^{\dagger}$ Variable adjusted for breed $\times$ total lipids; ${ }^{\ddagger}$ Variable adjusted for total lipids; ${ }^{*}$ Variable adjusted for breed $\times$ diet $\times$ total lipids.

$(P<0.001)$ in Barrosã when compared to Alentejana bulls. Alentejana bulls had the highest percentages of total, $n-3$ and $n-6$ PUFA $(P<0.001)$. The $14: 0$ percentages were higher $(P=0.003)$ in the low silage than in the high silage fed bulls. Barrosã bulls fed the low silage diet had the highest 16:0 fatty acid proportions (breed $\times$ diet, $P=0.003)$. Deposition of $20: 4 n-6$ varied according to breed and diet $(P<0.001$ and $P=0.001$, respectively), with Alentejana having higher percentages than Barrosã bulls, and low silage promoting lower deposition in comparison to high silage diet. Feeding the low silage diet resulted in higher percentages $(P=0.038)$ of TFA in comparison to the high silage diet. The BCFA were higher $(P<0.001)$ in animals fed on the high silage diet. Bulls fed the high silage diet had higher $n$ - 3 PUFA percentages $(P<0.001)$ than those fed the low silage diet. The Barrosã bulls fed the low silage diet had the lowest percentages of $18: 2 n-6$ (breed $\times$ diet, $P=0.007$ ). The deposition of 18:0 was similar $(P>0.05)$ across the four experimental groups.

\section{Gene expression in subcutaneous adipose tissue}

The relative mRNA expression levels of the nine lipid metabolism key factors analysed in the SAT are presented in Figure 1. CRAT, LPL and SCD showed higher expression levels in the Barrosã breed when compared to the Alentejana animals $(P<0.05)$, corresponding to a fold-change of $1.46,1.56$ and 1.74 , respectively. In addition, the Barrosã breed tended $(P=0.081)$ to have higher expression levels (1.47-fold) of SREBF1 than the Alentejana bulls. The low silage diet promoted the SREBF1 up-regulation (1.64-fold) in comparison to the high silage diet $(P=0.028)$. Concerning the $A C A C A$ mRNA levels, while the Barrosã bulls fed the low silage diet tended to have higher expression levels than the high silage fed ones (2.24-fold), no variation between dietary treatments were found for the Alentejana bulls (breed $\times$ diet, $P=0.082$ ). A similar pattern was observed for the PPARA gene expression levels (1.6-fold, breed $\times$ diet, $P=0.061)$. As for the FABP4 gene expression, higher expression levels were found in the low silage fed Barrosã 


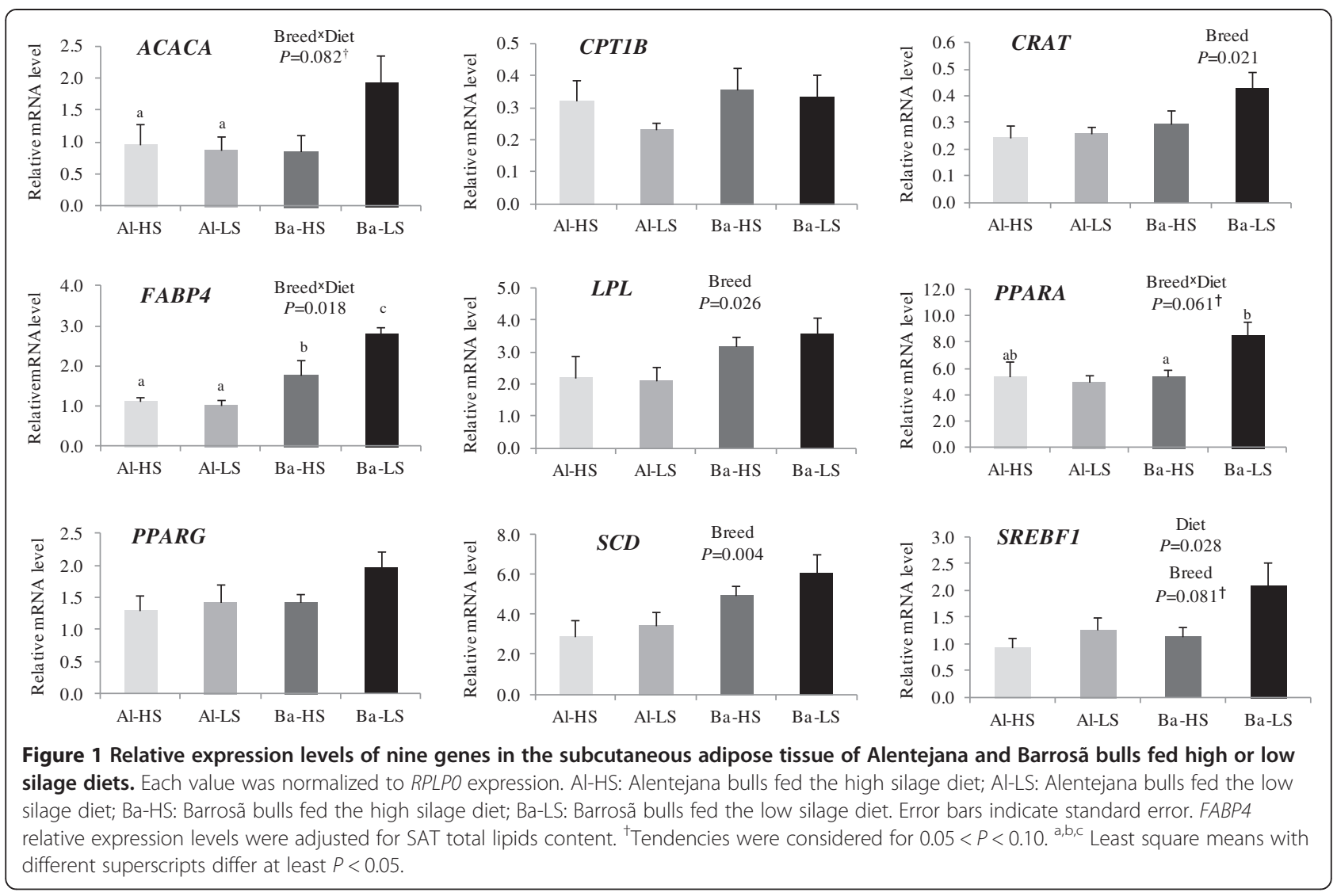

bulls when compared to those fed the high silage diet (1.55fold), whilst in the Alentejana bulls there were no variations between feeding regimens (breed $\times$ diet, $P=0.022$ ).

\section{Gene expression in muscle}

The relative mRNA expression levels of the nine lipid metabolism key factors analysed in the LL muscle are presented in Figure 2. The CPT1B encoding gene tended to have higher expression levels (1.18-fold) in the Barrosã breed when compared to the Alentejana bulls $(P=0.057)$. The PPARG gene showed a similar tendency (1.28-fold, $P=0.081$ ). The ACACA mRNA levels tended to be 1.19-fold higher in the low silage diet fed bulls when compared to the high silage fed ones $(P=0.053)$. Conversely, the mRNA levels of $L P L$ tended $(P=0.083)$ to be higher (1.29-fold) in the high silage fed bulls than in their low silage fed counterparts. The FABP4 gene showed higher expression levels (3.83-fold) in the low silage fed when compared to the high silage fed bulls $(P=0.007)$, corresponding to a fold-change of 3.83. The expression levels of CRAT, PPARA, SCD and SREBF1 genes were similar across experimental groups $(P>0.05)$.

\section{Correlation between gene expression and fatty acids} In order to elucidate the possible contribution of the lipogenic enzymes for fatty acid composition in SAT and muscle, the relationship between levels of gene expression and the content on main fatty acids was determined (Table 3).

For SAT, the correlation analysis revealed a positive relationship between total lipid content and FABP4 gene expression level $(r=0.38)$. In addition, this analysis showed negative correlations between this gene and 16:0 and 18:0 fatty acids ( $r=0.45$ and $r=0.41$, respectively). Furthermore, positive correlations were found for FABP4 expression level and 18:1c9 $(r=0.34), 18: 1 c 11 \quad(r=0.37)$ and $c 9, t 11$-CLA $(r=0.58)$, as well as for SFA $(r=0.51)$ and MUFA $(r=0.48)$. LPL gene expression had a negative association with 14:0 $(r=-0.33)$ and 16:0 $(r=-0.42)$, as well as the SFA $(r=-0.34)$. In addition, positive correlations were found between $L P L$ mRNA expression levels and total lipids $(r=0.34), 18: 1 c 9$ $(r=0.48)$ and $c 9, t 11-$ CLA $(r=0.35)$, as well as with MUFA $(r=0.35)$. The $S C D$ gene expression and the proportions of both $18: 1 c 9$ and $c 9, t 11$-CLA were positively correlated ( $r=0.51$ and $r=0.45$, respectively). A moderate association was also observed between $S C D$ gene expression and MUFA $(r=0.43)$. In addition, there was a negative correlation between 16:0 and expression of the $S C D$ gene $(r=-0.48)$. Concomitantly, SFA and $S C D$ gene expression were also negatively correlated $(r=-0.44)$. 


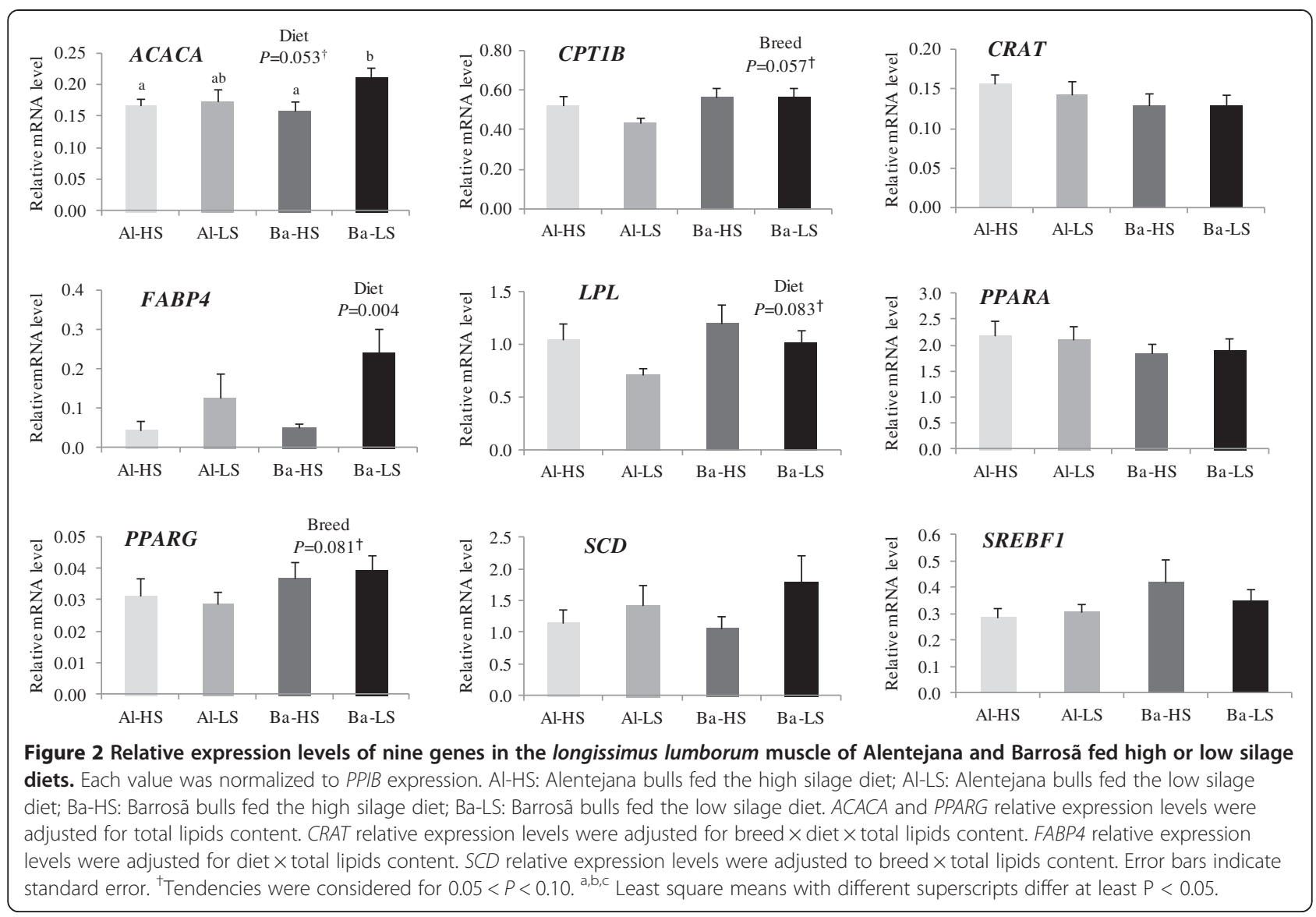

Concerning the muscle, ACACA expression levels were correlated with total lipids $(r=0.48)$, and the percentages of TFA $(r=0.40)$. Correlations were also found between FABP4 mRNA levels and total lipids $(r=0.36)$, 18:1c9 $(r=0.42)$, and MUFA $(r=0.38)$. The mRNA levels for PPARA gene were negatively related to $18: 1 c 9$ $(r=-0.33)$ percentages. Levels of PPARG expression were associated with the percentages of 14:0 $(r=0.35)$. A positive association was found for $S C D$ mRNA levels and TFA $(r=0.39)$. Finally, $18: 1 c 11$ and TFA showed positive correlations $(r=0.48$ and $r=0.33$, respectively) with the expression levels of the SREBF1 gene.

\section{Principal components analysis}

A Principal Components Analysis (PCA) was applied to a data set of fatty acid composition and gene expression parameters in order to describe the variability of the pooled data into two dimensions (Figure 3A). The score plot of the first two components explains $70.1 \%$ of the total variability, with $57.1 \%$ for $\mathrm{PC} 1$ and $13.0 \%$ for PC2 (Table 4). In the score plot, there is a clear separation of most genes from the main fatty acids, except 18:1c9 and CLA (c9t11). Most of the genes were allocated on the right side of the plot (quadrant $b$ ), clearly separated from the other variables, showing positive scores for the PC1 and little influence on the PC2. In contrast, the CPT1 gene was located on quadrant $a$, with positive scores for $\mathrm{PC} 2$.

The PC1, which explains $57 \%$ of the variability, separated tissues (SAT $v s$ muscle), with lipogenic genes and total lipids associated with SAT metabolism (quadrants $b$ and $c$ ). The PC2, which explains $13 \%$ of the variability, separated palmitic (16:0) and myristic (14:0) fatty acids (quadrant $c$ ) from the remaining fatty acids. In quadrant $b$, a cluster was defined by $A C A C A, C R A T, L P L, S C D$, SREBF1 and PPARA genes. In addition, a cluster was formed by CLA, oleic acid (18:1c9) and the FABP4 gene. The score plot depicted in Figure 3B shows the location of the LL muscle and SAT samples in the multivariate space of the first two PCs. These scores were clearly arranged in two clusters, corresponding to each tissue. In addition, for SAT there was some degree of separation between Alentejana (mostly located on quadrant $a$ ) and Barrosã bulls (mostly located on quadrant $d$ ), whereas for muscle the distinction between experimental groups was not so clear.

\section{Discussion}

The deposition of fat and fatty acids in animal tissues has been ascribed to a complex regulation network of 
Table 3 Pearson's correlation coefficients between genes expression levels and fatty acid composition in subcutaneous adipose tissue and longissimus lumborum muscle from Alentejana and Barrosã breeds ${ }^{1-2}$

\begin{tabular}{|c|c|c|c|c|c|c|c|c|c|c|c|}
\hline & TL & $14: 0$ & $16: 0$ & $18: 0$ & 18:1t11 & 18:1c9 & 18:1c11 & CLA & SFA & MUFA & TFA \\
\hline \multicolumn{12}{|l|}{ SAT } \\
\hline$A C A C A$ & 0.22 & -0.10 & -0.16 & -0.11 & 0.09 & 0.26 & -0.1 & 0.25 & -0.17 & 0.19 & 0.06 \\
\hline CPT1B & -0.02 & -0.04 & -0.09 & 0.20 & -0.04 & -0.06 & 0.08 & 0.04 & 0.07 & -0.05 & -0.14 \\
\hline CRAT & 0.21 & -0.13 & -0.25 & -0.12 & 0.12 & 0.27 & -0.15 & 0.26 & -0.22 & 0.20 & 0.10 \\
\hline FABP4 & $0.38^{*}$ & -0.22 & $-0.45^{* *}$ & $-0.41 *$ & 0.27 & $0.34^{*}$ & $0.37^{*}$ & $0.58^{* * *}$ & $0.51^{* * *}$ & $0.48^{* *}$ & 0.28 \\
\hline$L P L$ & $0.34^{*}$ & $-0.33^{*}$ & $-0.42^{* *}$ & -0.16 & 0.15 & $0.48^{* *}$ & -0.08 & $0.35^{*}$ & $-0.34^{*}$ & $0.35 *$ & 0.07 \\
\hline PPARA & 0.21 & -0.10 & -0.18 & -0.14 & -0.03 & 0.28 & -0.11 & 0.20 & -0.19 & 0.23 & -0.05 \\
\hline PPARG & 0.14 & -0.20 & -0.13 & -0.12 & -0.04 & 0.25 & 0.02 & 0.10 & -0.18 & 0.21 & 0.02 \\
\hline$S C D$ & 0.24 & -0.31 & $-0.48^{* *}$ & -0.26 & 0.13 & $0.51^{* *}$ & -0.03 & $0.45^{* *}$ & $-0.44^{* *}$ & $0.43^{* *}$ & 0.15 \\
\hline SREBF1 & 0.15 & -0.19 & -0.16 & -0.19 & -0.01 & 0.26 & 0.00 & 0.19 & -0.23 & 0.24 & 0.08 \\
\hline \multicolumn{12}{|l|}{ Muscle } \\
\hline$A C A C A$ & $0.48^{* *}$ & 0.15 & 0.20 & 0.01 & 0.25 & 0.20 & 0.10 & 0.14 & 0.20 & 0.23 & $0.40^{*}$ \\
\hline CPT1B & 0.13 & -0.05 & -0.06 & 0.00 & 0.18 & 0.14 & 0.28 & 0.20 & -0.11 & 0.21 & 0.05 \\
\hline CRAT & -0.17 & -0.18 & -0.13 & 0.20 & -0.16 & -0.11 & 0.17 & -0.30 & 0.05 & -0.10 & $-0.33^{*}$ \\
\hline FABP4 & $0.36^{*}$ & 0.19 & 0.20 & -0.16 & 0.26 & $0.42^{* *}$ & -0.11 & 0.17 & 0.07 & $0.38^{*}$ & 0.21 \\
\hline$L P L$ & 0.09 & -0.03 & -0.05 & -0.21 & 0.02 & 0.27 & -0.06 & 0.14 & -0.21 & 0.25 & -0.13 \\
\hline PPARA & -0.19 & 0.08 & 0.17 & -0.06 & -0.30 & $-0.33^{*}$ & 0.01 & -0.21 & 0.09 & -0.30 & -0.27 \\
\hline PPARG & 0.21 & $0.35^{*}$ & 0.28 & -0.27 & 0.17 & 0.22 & -0.18 & 0.30 & 0.03 & 0.23 & 0.09 \\
\hline$S C D$ & 0.25 & -0.05 & 0.04 & 0.08 & 0.26 & 0.13 & 0.14 & 0.13 & 0.19 & 0.12 & $0.39^{*}$ \\
\hline SREBF1 & 0.08 & 0.14 & 0.16 & -0.01 & 0.05 & -0.14 & $0.48^{* *}$ & 0.31 & 0.13 & 0.03 & $0.33^{*}$ \\
\hline
\end{tabular}

${ }^{1} T L$, total lipids; $S A T$, subcutaneous adipose tissue.

${ }^{2}$ Significance level * $P<0.05 ;{ }^{* *}, P<0.01 ;{ }^{* * *}, P<0.001$.

lipogenic genes, although the molecular mechanisms underlying these systems remain to be established. Considering that adipose tissue physiology is related to both meat quality and animal production efficiency, understanding the factors affecting the depot-specific fat accretion and metabolism in beef cattle is of paramount importance. The present study addressed these aspects based on an experimental trial with two genetically diverse bovine breeds with distinct maturity rates, Alentejana and Barrosã, fed diets with different silage to
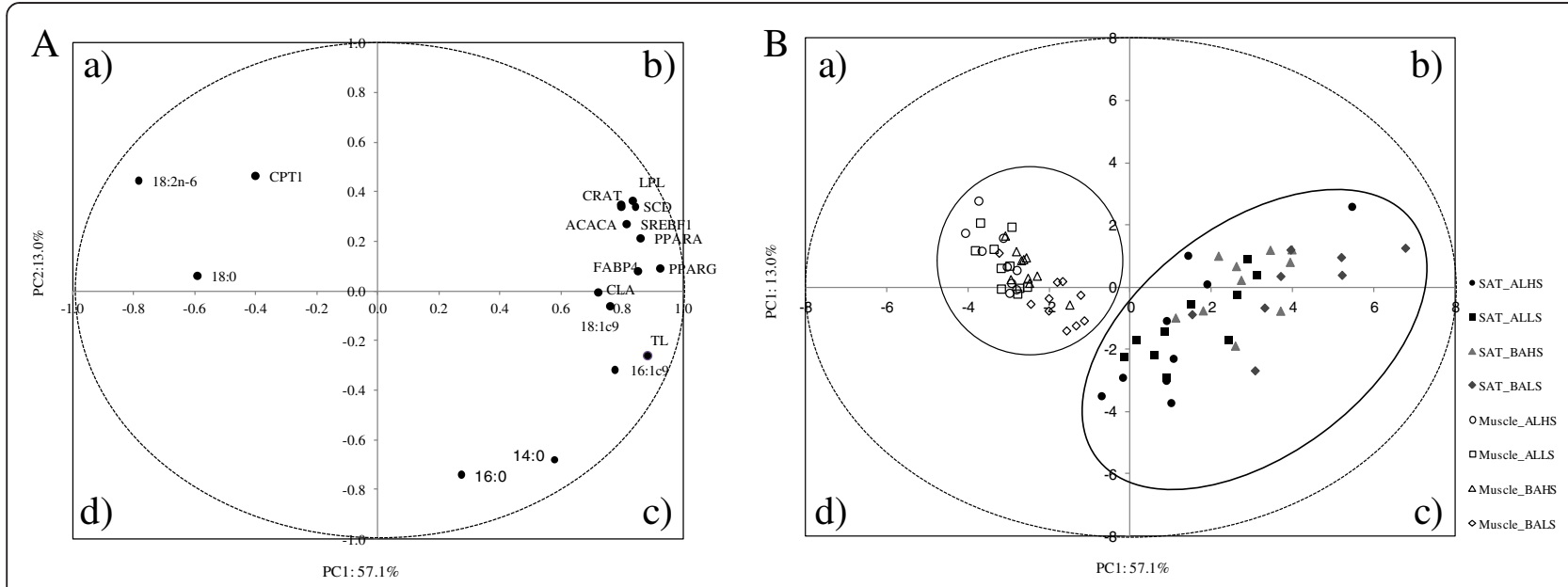

Figure 3 Loading plot of the first and second principal components (PC) of the pooled data (A) and component's score vectors (B) for longissimus lumborum muscle and subcutaneous adipose tissue from Alentejana and Barrosã bulls fed high or low silage diets. TL: total lipids; SAT: subcutaneous adipose tissue; Al-HS: Alentejana bulls fed the high silage diet; Al-LS: Alentejana bulls fed the low silage diet; Ba-HS: Barrosã bulls fed the high silage diet; Ba-LS: Barrosã bulls fed the low silage diet. 
Table 4 Loadings for the first three principal components ${ }^{1}$

\begin{tabular}{lccc}
\hline Variable & PC1 & PC2 & PC3 \\
\hline TL & 0.883 & -0.259 & 0.021 \\
$14: 0$ & 0.579 & -0.681 & 0.260 \\
$16: 0$ & 0.274 & -0.740 & 0.526 \\
$16: 1 C 9$ & 0.778 & -0.319 & -0.415 \\
$18: 0$ & -0.592 & 0.060 & 0.643 \\
18:1C9 & 0.762 & -0.062 & -0.327 \\
CLA & 0.723 & -0.006 & -0.492 \\
18:2n-6 & -0.784 & 0.443 & -0.051 \\
ACACA & 0.799 & 0.339 & 0.297 \\
CRAT & 0.798 & 0.348 & 0.211 \\
CPT1 & -0.402 & 0.464 & 0.092 \\
LPL & 0.836 & 0.364 & 0.120 \\
PPARA & 0.862 & 0.212 & 0.215 \\
PPARG & 0.926 & 0.091 & 0.188 \\
FABP4 & 0.853 & 0.080 & -0.152 \\
SCD & 0.845 & 0.341 & 0.077 \\
SREBF1 & 0.816 & 0.270 & 0.234 \\
Proportion of variance (\%) & 57.10 & 13.04 & 9.43 \\
Cumulative variance (\%) & 57.10 & 70.14 & 79.57 \\
\hline PPC principa componen & & &
\end{tabular}

${ }^{1} P C$ principal component, $T L$ total lipids.

concentrate ratios (30/70\% vs. 70/30\%). Albeit phylogenetically distant [18], Alentejana and Barrosã breeds are, nevertheless, more genetically similar than the breeds used in previous studies addressing adipogenic gene expression differences, mainly based on the Japanese Black genotype [20-22]. Nonetheless, results reported here indicate that genetic background and, to a lesser extent diet composition, determine fat content and composition, pointing out to a differential fat partitioning between subcutaneous and intramuscular fat in Alentejana and Barrosã breeds.

In order to elucidate the molecular mechanisms involved in this physiological process, these breed- and diet-specific variations are explained here through the transcript levels of nine key lipid metabolism-related genes. The PCA showed a close relationship among all adipogenic and lipogenic genes, which separated distinctively from $C P T 1$ gene, involved in the $\beta$-oxidation pathway, but not CRAT. PPARG is a key activator of adipocyte differentiation and insulin sensitivity [23], inducing the transcription of many adipocyte genes encoding proteins and enzymes involved in the development and the maintenance of the adipocyte phenotype [24]. Surprisingly, levels of expression of PPARG were kept unchanged among experimental groups in the SAT samples, although Barrosã breed tended to have higher expression levels in the muscle than Alentejana bulls. It was expected that Barrosã breed, being a precocious breed, would had a greater proportion of adipocytes undergoing differentiation and, therefore, would had a greater relative expression of PPARG than Alentejana bulls. Although PPARG expression peaks during adipocyte differentiation, it is also expressed in mature adipocytes, but at lower levels [2]. Harper and Pethick [25] reported that the expression of PPARG decreases substantially as growth proceeds. Therefore, treatment differences may not have been detected if one group had adipocytes undergoing differentiation, whereas the other group may have greater number of mature adipocytes resulting in similar PPARG expression levels. Differences could, however, be detected at earlier stages of development. These results can be explained by the circumstance that subcutaneous fat develops earlier than intramuscular fat and, therefore, the tendency observed in the muscle was not detected in the SAT.

The SREBF1 gene encodes a transcription factor involved in adipocyte differentiation [26] and in the biosynthesis of fatty acids [27] being, possibly, implicated in a mechanism that links adipogenesis and lipogenesis. In particular, the SREBF1c isoform appears to be primarily involved in regulating the expression of lipogenic and fatty acid-metabolizing enzymes. The transcription and activation of SREBF1c protein was proposed to be regulated by the degree of saturation of lipids [28]. Graugnard et al. [29] suggested that the expression of the SREBF1 gene could be nutritionally regulated. Transcriptional regulation of SREBF1 in most non-ruminant animals is sensitive to insulin, which under times of carbohydrate excess leads to stimulation of fatty acid synthesis and TAG deposition in adipose tissue [30]. In the present study, insulin levels were also the highest in low silage fed bulls [31], as were the expression levels of SREBF1 in the SAT. Although the transcription factor SREBF1 is considered to regulate $S C D$ expression [32], its expression levels were not consistent with that of $S C D$ in the muscle.

As pre-adipocytes differentiate into mature adipocytes, $L P L$ is one of the first genes expressed due to its role in the de novo fatty acid synthesis [24]. A higher relative LPL mRNA expression in the SAT could indicate that Barrosã bulls had more adipocytes undergoing differentiation when compared to Alentejana bulls. Pickworth et al. [2] proposed that $L P L$ may be a more definitive indicator of adipocyte differentiation than PPARG. Concerning the relationships between the fatty acids and $L P L$ expression in SAT, the correlation analysis revealed close relationships between levels of $L P L$ mRNA and $18: 1 c 9$, as well as $c 9, t 11-C L A$, among others. These results highlight the role of $L P L$ in the control of TAG uptake and, consequently, on the fatty acid profile. However, the same pattern was not observed for the muscle and $L P L$ showed no clear association with the main fatty 
acids. Taking into account that both $S C D$ and $L P L$ are expressed late in adipogenesis, increased gene expression would be consistent with more active adipocytes in SAT from Barrosã than in Alentejana bulls. Taken together, these results suggest that Barrosã bulls may have more differentiated adipocytes, which are capable of storing fat in the subcutaneous depot.

FABP4 protein is responsible for the transport of fatty acid outside the cell [33] and plays a role in lipolysis and fatty acid trafficking in different tissues [34-36]. Fat storage and metabolism within functional adipocytes are modulated by FABP4 [24], and thus levels of expression of this gene can be used as a marker of fully differentiated adipocytes [2]. In fact, its association with intramuscular fat content and backfat thickness have been reported by Jurie et al. [37]. Results herein presented for FABP4 expression are concomitant with a higher fatty acids deposition in the SAT from Barrosã when compared to Alentejana bulls. The higher expression levels of FABP4 in Barrosã bulls fed the low silage diet may be indicative of a higher level of adipogenic differentiation in the SAT of these animals. Several studies reported an association between bovine FABP4 gene expression or protein activity and intramuscular fat content $[8,26,37]$, as well as backfat depth [38]. Accordingly, in this study, the Barrosã carcasses had the highest intramuscular fat and carcass fatness scores (data not shown). Furthermore, levels of FABP4 expression were moderately associated with total lipids contents in the muscle, as well as with the 18:1c9 proportions and the associated desaturation index. On the other hand, FABP4 was associated with the main fatty acids in the SAT. These results reinforce the role of FABP4 in intramuscular fat development and the SAT as the major site for lipid metabolism in ruminants.

ACACA is a key regulator of lipogenesis and the ratecontrolling enzyme in adipose tissue of meat-producing animals [39]. The expression of the ACACA gene is highly inducible in the major lipogenic tissues [39] and the enzyme is nutritionally regulated [40,41]. In a study by Joseph et al. [41], it was found that oleic acid had an inhibitory effect on the expression of lipogenic genes in the SAT. In line with this, data herein presented revealed that, in SAT, ACACA expression levels tended to be the highest in Barrosã bulls fed the low silage diet (lowest oleic acid content). However, in the muscle, the expression levels tended to be lower in the high silage fed animals. These results suggested that the effect of dietary fatty acid composition is not only influenced by the genetic background but also by the fat depot location. In addition, $A C A C A$ mRNA levels were shown to have a positive association with total lipid content in the muscle samples, thus adding evidence to the importance of this enzyme to intramuscular fat deposition in ruminants.
Dietary $n-3$ and $n-6$ PUFA have been shown to inhibit de novo lipogenesis in dairy cattle [42]. Accordingly, our results showed a tendency for higher $A C A C A$ expression levels in the muscle from the low silage- in comparison to the high silage-fed bulls. Underwood et al. [43] reported a positive relationship between ACACA enzyme activity and intramuscular fat, which is consistent with our findings. In the present study, total lipids in the muscle were positively related to the expression of $A C A C A$. Although this gene codifies for an enzyme which catalyses the formation of SFA, there was a positive association between $A C A C A$ expression levels and TFA. This suggests that an increase in TFA biosynthesis, that is, in desaturase activity, is a major factor in intramuscular (but not SAT) deposition in ruminants. In addition, $C P T 1 B$ tended to show lower expression levels in the muscle from Alentejana, indicating higher fatty acid oxidation in the Barrosã breed.

Results concerning $S C D$ gene expression, considered a marker of mature adipocytes [29], support the concept of a higher degree of maturity of the SAT adipocytes from the Barrosã than the Alentejana bulls, as observed for the FABP4 gene. The fatty acid composition of SAT mirrors the action of the SCD protein on substrates like stearic and palmitic acids. The correlation analysis between oleic acid proportions and $S C D$ expression levels in the SAT was showed to be positive and significant. This result is in agreement with previous reports [44] that reported that increased SCD activity is, at least partially, responsible for an elevated oleic acid, the main MUFA, content in ruminant. Similarly, a significant correlation was also found between $c 9, t 11$-CLA percentage and $S C D$ expression levels. Taniguchi et al. [22] reported a positive correlation between levels of $S C D$ mRNA and MUFA proportion, which led to the conclusion that $S C D$ expression might contribute to the differences in the SAT fatty acid composition between breeds. The variations observed in the fatty acid classes in the SAT and muscle samples were mostly due to breed. High MUFA proportions in SAT have been reported [12] and might be related to an elevated SCD activity. Overall, our results support the concept of a central role for $S C D$ in adipose tissue fatty acid synthesis. Genes encoding lipogenic enzymes responsible for the de novo SFA synthesis and MUFA production were down-regulated in Alentejana breed when compared to Barrosã bulls. This is in agreement with changes in tissue fatty acid composition, in which 16:0 concentration, the end product of de novo SFA synthesis, and $c 9, t 11-$ CLA, a product of delta-9 desaturation, were reduced in the SAT of Alentejana bulls when compared to that of Barrosã animals.

In contrast to what was observed in SAT, the expression levels of the $S C D$ gene in the muscle were similar 
among the four experimental groups. Several authors reported that $S C D$ mRNA [26] or protein expression levels [45] in muscle do not reflect intramuscular fat levels. The results herein reported are consistent with those of the previous studies. In addition, an association between SCD mRNA levels and MUFA contents in bovine SAT has been reported in several works [46-48]. Nonetheless, the same association has not been reported for muscle $[45,47,49]$, which could point to a depotspecific regulation mechanism of $S C D$ gene expression and/or enzyme activity. Finally, it should also be noted that there was a high individual variation in the SCD mRNA levels. Therefore, despite changes in relative gene expression mirroring the changes in MUFA proportion, the correlation analysis failed to establish a significant association between both. The lack of association between $c 9, t 11-C L A$ and $S C D$ expression is in agreement with data reported by both Ward et al. [42] and Bartoň et al. [50]. Positive correlations, however, were found between the levels of SCD gene expression and total lipids, as well as TFA, both of which increase as fattening proceeds [51]. It should however be taken into account that conclusions drawn from single-point observations may lead to the erroneous assumption that $S C D$ was not affected and/or had a crucial role in intramuscular fat synthesis. In that regard, Graugnard et al. [29] suggested that responses to high starch diets might not necessarily lead to increased adipogenesis. Moreover, these authors reported with some surprise that animals fed a low starch/high fibre diet during the growing phase showed increases in expression of lipogenic genes PPARG, $F A B P 4$, and $S C D$ during the finishing phase.

The PPARA gene induces the expression of the fatty acid $\beta$-oxidation genes $[50,52]$. The tendency for a higher expression of PPARA in the SAT from Barrosã bulls fed the low silage diet in comparison to the remaining experimental groups is concomitant with a more intense $\beta$-oxidation in the former breed. In addition, PPARA has been shown to induce the expression of delta-5 and delta- 6 desaturase genes [53]. However, results from the present study revealed no clear association between the PPARA mRNA levels and the fatty acid composition of SAT.

Carnitine acyltransferases catalyse the exchange of acyl groups between carnitine and coenzyme A (CoA) [54]. These enzymes include CRAT and carnitine palmitoyltransferases (CPTs) [54]. The CPTs transesterify medium and long chain fatty acyl chains, whereas CRAT transesterifies short-chain acyl chains [55]. High CRAT gene transcription levels may be indicative of an elevated number of differentiating cells during growth [54]. The higher CRAT transcription levels found in the Barrosã bulls are in agreement with the higher lipid accumulation in the Barrosã SAT, in comparison to the Alentejana bulls. In contrast, the lack of a significant variation in their relative expression levels of both genes' in muscle samples is in agreement with the similar expression levels observed for the genes indicative of terminal adipocyte differentiation (SCD, LPL and PPARG). In addition, the close association between CRAT and the genes involved in lipogenesis reinforces the relationship between lipogenesis and $\beta$-oxidation, thus being indicative of high lipid turnover in those animals with high lipid deposition.

If in SAT there was a clear effect of breed in fatty acid deposition, with no influence of diet composition, in the LL muscle the response to dietary silage levels depended on animals' genetic background. In previous studies $[56,57]$, diets differing in starch contents (high starch $v s$. low starch), which is also the case of the present study, resulted in higher intramuscular fat in animals fed high starch diets. The interaction between breed and diet found suggests that the concept that high concentrate diets increase beef intramuscular [13] may be determined by breed and/or maturity. The differential response to diet composition between Alentejana and Barrosã bulls suggests distinct ruminal biohydrogenation patterns, as indicated by the intramuscular fatty acids contents, as well as the increased 18:2n-6 metabolic availability in Alentejana bulls fed the low silage diet. A differential regulation of fatty acid metabolism in distinct fat depots could explain the fact that no similar response was observed in SAT. Indeed, various fat depots have been reported to differ markedly in lipogenic activity $[58,59]$. An increase in the SFA content is to be expected whenever the concentrate proportion in the diet is increased. Feed silage level had no effect on total SFA of both tissues. However, in the SAT stearic acid was higher in high silage than in low silage fed bulls, and also higher in Alentejana when compared to Barrosã breed, but no such effects were found in the LL muscle. Similarly, both total and individual MUFA were not responsive to dietary silage level in the SAT, whereas in the LL muscle a tendency was found for the low silage diet to promote higher percentages of these fatty acids. Both PUFA and TFA were influenced by breed and diet, but the response to breed and diet factors differed between tissues. The BCFA were the only fatty acids showing similar response to diet, given that they originate ruminal activity and suffer no further modifications until being deposited in tissues. Taken together, these results suggest a differential regulation of fatty acid metabolism between tissues, possibly resulting from the contrasting roles of intramuscular and subcutaneous fat depots. In addition, the data also indicate differences in genetic background reflected in the response to diet composition, both in the gene expression of adipogenic and lipogenic factors and fatty acid composition of tissues. 
The PCA confirmed the tissues contrasting features regarding lipid metabolism and fatty acid composition, showing a clear separation between the muscle and the SAT, as was previously shown by the analysis of variance. In addition, this statistical approach showed that there is less variability in muscle fatty acid composition and gene expression when compared to the SAT, as depicted by the plot of component scores. Furthermore, the PCA indicates that the expression levels of most adipogenic and lipogenic genes, along with linoleic acid, are the variables with the most discriminant power between tissues.

\section{Conclusions}

The results herein presented suggest that, at 18 months old, Barrosã bulls might have more differentiated adipocytes and lipids deposited in SAT than Alentejana animals. Moreover, both lipogenesis (SCD and $L P L)$ and $\beta$-oxidation (CRAT) related genes had higher levels of mRNA in the SAT from Barrosã animals when compared to Alentejana bulls. These data indicate a higher storage/removal ratio of TAG and a greater dynamics of lipid turnover in the SAT of Barrosã breed relative to Alentejana bulls.

The fatty acid deposition in the SAT is mainly influenced by dietary silage level, whereas the effect of breed is mostly associated with the expression level of the transcription factor SREBF1. Combined effects of breed and diet were obtained for the de novo fatty acid synthesis $(A C A C A)$ and fatty acid transport in adipocytes $(F A B P 4)$ related genes, and the transcription factor PPARA mRNA levels.

In contrast to SAT, only a slight breed effect was obtained for muscle, with the expression levels of PPARG and CPT1B showing a tendency to be higher in Barrosã bulls. However, the low silage diet, relative to the high silage diet, increased the levels of FABP4 and $A C A C A$ mRNA and tended to decrease $L P L$ expression in the muscle.

Taken together, the results herein presented show that lipid metabolism in SAT is more sensitive to breed than muscle, whereas lipid metabolism in the latter tissue appears to be mostly diet-dependent. The differential gene expression patterns in SAT and muscle are likely responsible for the fatty acid partitioning between both tissues, thus reinforcing the prevailing role of SAT over intramuscular fat in the de novo fatty acid synthesis. These findings provide evidence for breed- and tissue-specific variations in fatty acid content and composition of beef cattle, which can be explained, at least in part, by the expression of key adipogenic and lipogenic genes involved in lipid metabolism. This insight into the molecular mechanisms underlying fat deposition in bovine SAT and muscle in different breed may contribute to the development of diet-based strategies to improve competitiveness of beef industry in order to satisfy consumers' expectations.

\section{Methods}

\section{Animals and experimental diets}

All experimental procedures involving animals were reviewed by the Ethics Commission of CIISA/FMV and approved by the Animal Care Committee of the National Veterinary Authority (Direcção-Geral de Veterinária, Lisbon, Portugal), following the appropriated European Union guidelines (Directive 86/609/EEC). This trial was conducted at the facilities of Unidade de Produção Animal, L-INIA, INRB (Fonte Boa, Vale de Santarém, Portugal), from January to November 2009. Forty young bulls from Alentejana $(n=20)$ and Barrosã $(n=20)$, were assigned to high or low forage based diets (four experimental groups of 10 animals each). One Alentejana bull from the high silage fed group was later removed from the trial due to a limp. Diets were composed of $30 / 70 \%$ (low silage) and 70/30\% (high silage) of maize silage and concentrate, respectively. The detailed proximate and fatty acid composition of the experimental diets has been published in a previous paper [60]. Briefly, crude fat and starch were higher in the low silage (31.7 and $376 \mathrm{~g} / \mathrm{kg}$ DM, respectively) than in the high silage diet (28.7 and $285 \mathrm{~g} / \mathrm{kg} \mathrm{DM}$, respectively). Conversely, the high silage diet had higher crude fibre and NDF contents (198 and $403 \mathrm{~g} / \mathrm{kg} \mathrm{DM}$, respectively) in comparison to the low silage diet (150 and $321 \mathrm{~g} / \mathrm{kg} \mathrm{DM}$, respectively). The low silage diet had lower palmitic (20.2 vs. $24.1 \%$ ) and stearic acid (5.1 vs. 9.4\%) percentages than the high silage diet, while the latter showed higher proportions of $20: 0$ (6.5 vs. 3.7\%), 18:2n-6 (43.9 vs. $40.9 \%$ ) and 18:3n-3 (9.2 vs. 6.0\%). Animals were housed in eight adjacent pens, two pens per breed and diet. The initial age was $331 \pm 32$ days for Alentejana bulls (average weight of $266 \pm 45.8 \mathrm{~kg}$ ) and $267 \pm 10$ days for Barrosã bulls (average weight of $213 \pm 16.3 \mathrm{~kg}$ ). All animals were slaughtered at 18 months of age, which is the commercial slaughter age for bulls in Portugal. Slaughters were performed at the INRB experimental abattoir by exsanguination, after stunning with a cartridge-fired captive bolt stunner.

Results concerning productive performance were described previously [61]. Briefly, Alentejana bulls fed the high silage diet had an average weight of $622 \pm 17.7 \mathrm{~kg}$ at slaughter, whereas the average weight for those fed the low silage diet was $636 \pm 29.7 \mathrm{~kg}$. Regarding Barrosã bulls, the weight at slaughter was $457 \pm 8.88 \mathrm{~kg}$ for those fed the high silage diet and $497 \pm 23.0 \mathrm{~kg}$ for bulls fed the low silage diet. Dry matter intake and average daily gain were higher in Alentejana when compared to Barrosã bulls, although feed efficiency was similar across 
experimental groups. Fatness scores were higher in Barrosã than in Alentejana bulls. Moreover, the low silage fed animals had higher fatness scores than those fed the high silage diet.

\section{Sample collection}

Immediately after slaughter, samples of longissimus lumborum muscle and SAT for gene expression analysis were collected from the right side of carcass at the 5th lumbar vertebra level, rinsed with sterile RNAse-free cold water solution, cut into small pieces (thickness of $\sim 0.3 \mathrm{~cm}$ ), stabilised in RNA Later solution (Qiagen, Hilden, Germany) and subsequently stored at $-80^{\circ} \mathrm{C}$. A second sample of SAT was vacuum-packed and stored at $-20^{\circ} \mathrm{C}$, until lipid extraction and determination of fatty acid composition.

Carcasses were suspended from the Achilles tendon, chilled at $10^{\circ} \mathrm{C}$ for 24 hours and aged during 8 days at $2^{\circ} \mathrm{C}$. The left half carcass was subsequently separated into commercial joints. The LL muscle samples (ca. $200 \mathrm{~g}$ ) were collected, trimmed of connective and adipose tissues before being blended in a food processor, vacuum packed and stored at $-20^{\circ} \mathrm{C}$ until lipid analysis.

\section{Total lipid content and fatty acid composition}

SAT and longissimus lumborum muscle samples were lyophilised $\left(-60^{\circ} \mathrm{C}\right.$ and $\left.2.0 \mathrm{hPa}\right)$, maintained at $-20^{\circ} \mathrm{C}$ (SAT) or dissecated at room temperature (muscle) and analysed within two weeks. Total lipids were extracted by the method of Folch et al. [62], using dichloromethane and methanol $(2: 1 \mathrm{v} / \mathrm{v})$ instead of chloroform and methanol $(2: 1 \mathrm{v} / \mathrm{v})$, as modified by Carlson [63].

Fatty acids were then converted to methyl esters as described by Raes et al. [64], using sodium methoxide in anhydrous methanol $(0.5 \mathrm{~mol} / \mathrm{l})$ for $30 \mathrm{~min}$, followed by hydrochloric acid in methanol $(1: 1 \mathrm{v} / \mathrm{v})$ for $10 \mathrm{~min}$ at $50^{\circ} \mathrm{C}$. Fatty acid methyl esters (FAME) were extracted twice with $3 \mathrm{ml}$ of $n$-hexane and pooled extracts were evaporated at $35^{\circ} \mathrm{C}$, under a stream of nitrogen, until a final volume of $2 \mathrm{ml}$. The resulting FAME were then analysed by GC using a fused-silica capillary column (CP-Sil 88; $100 \mathrm{~m} \times 0.25 \mathrm{~mm}$ i.d., $0.20 \mathrm{~mm}$ film thickness; Chrompack, Varian Inc., Walnut Creek, CA, USA), equipped with a flame ionisation detector, as described by Bessa et al. [65]. The quantification of FAME used nonadecanoic acid (19:0) as the internal standard, added to lipids prior to saponification and methylation. The same FAME solution was used for the analysis of both fatty acid composition and $c 9, t 11$-CLA, enabling the direct comparison of quantitative data and eliminating differences in sample preparation. CLA isomers were individually separated by triple silver-ion columns in series (ChromSpher 5 Lipids; $250 \mathrm{~mm} \times 4.6 \mathrm{~mm}$ i.d., $5 \mu \mathrm{m}$ particle size; Chrompack, Bridgewater, NJ, USA), using a high performance liquid chromatography (HPLC) system (Agilent 1100 Series, Agilent Technologies Inc., Palo Alto, CA, USA) equipped with an autosampler and a diode array detector adjusted to $233 \mathrm{~nm}$, according to the procedure previously reported [66]. Fatty acid composition was expressed as g/100 g of total fatty acid content, assuming a direct relationship between peak area and fatty acid methyl ester weight.

\section{Total RNA extraction}

Frozen tissue samples were homogenized with an Ultra-Turrax ${ }^{\oplus}$ homogenizer (IKA-Labortechnik, Staufen, Germany). For SAT samples, total RNA was extracted using RNeasy Lipid Tissue Mini Kit(Qiagen Inc, Hilden, Germany) according to the manufacturer's protocol. Total RNA was extracted from muscle samples using Trizol reagent (Invitrogen, Carlsbad, CA, USA) and purified with the RNeasy Mini Kit (Qiagen Inc), according to the manufacturer's protocol. To exclude possible amplification of contaminating genomic DNA, an additional step of DNase digestion was performed with the RNase-free DNase Set (Qiagen Inc.), incubating samples with DNase for $15 \mathrm{~min}$ at room temperature. Total RNA extracts were immediately analyzed for quantity (OD260nm) and purity (OD260 nm/OD280 nm) (NanoDrop ND-2000 c, Peqlab $\mathrm{GmbH}$, Erlangen, Germany). RNA aliquots were stored at $-80^{\circ} \mathrm{C}$ and until further analysis.

\section{Synthesis of complementary DNA}

Single-stranded cDNA was synthesised using the High Capacity cDNA Reverse Transcription Kit (Applied Biosystems, Foster City, CA, USA) following the manufacturer's protocol. Each $20 \mu \mathrm{l}$ RT reaction contained $250 \mathrm{ng}$ (SAT) or $600 \mathrm{ng}$ (muscle) of RNA template, $50 \mathrm{nM}$ random RT Primer, $1 \times$ RT buffer, $0.25 \mathrm{mM}$ of each dNTPs, $3.33 \mathrm{U} / \mu \mathrm{l}$ multiscribe reverse transcriptase and $0.25 \mathrm{U} / \mu \mathrm{l}$ RNase inhibitor, at temperatures of $25^{\circ} \mathrm{C}$ for $10 \mathrm{~min}, 37^{\circ} \mathrm{C}$ for $120 \mathrm{~min}$, and $85^{\circ} \mathrm{C}$ for $5 \mathrm{~min}$ cDNA aliquots were stored at $-20^{\circ} \mathrm{C}$.

\section{Primer design and housekeeping gene stability evaluation}

Primer Express software (Applied Biosystems, Foster City, CA, USA) was used to design primers fixing the amplicon length to 65-150 bp (Table 5). When possible, primers were designed to fall across exon-exon junctions. Primers were aligned against publicly available databases using BLASTN at the National Center of Biotechnology Information. Prior to RT-qPCR the various sets of gene-specific primers were tested using a conventional PCR and run in a $2.5 \%$ agarose gel stained with ethidium bromide. Only those primers that presented a single band at the expected size in the gel, and thus no primer-dimer formation, were used for RT-qPCR. The 
Table 5 Primer pairs sequences for quantitative real-time $\mathrm{PCR}^{1-4}$

\begin{tabular}{|c|c|c|c|c|c|}
\hline Gene symbol & Full gene name & Acc. number ${ }^{1}$ & Primer pairs $\left(5^{\prime}-3^{\prime}\right)^{2}$ & Exons spanned & Product size (bp) \\
\hline \multirow[t]{2}{*}{$A C A C A$} & Acetyl-CoA carboxylase alpha & NM_174224 & F: ttc acg tgg cct ggg tag a & $40-41$ & 142 \\
\hline & & & $R:$ ttg tac ctg gat tct cct tca tct $t$ & & \\
\hline \multirow[t]{2}{*}{ CPT1B } & Carnitine palmitoyltransferase $1 \mathrm{~B}$ & NM_001034349 & F: gcg act cca gtg gga cat tc & $12-13$ & 114 \\
\hline & & & R: aaa ggc agg aac tgg aag ca & & \\
\hline \multirow[t]{2}{*}{ CRAT } & Carnitine O-acetyltransferase & NM_001075587 & F: ggc cca ccg agc cta cac & $12-13$ & 138 \\
\hline & & & R: atg gca atg gcg tag gag gt & & \\
\hline \multirow[t]{2}{*}{ FABP4 } & Fatty acid-binding protein 4 & NM_174314 & F: tgg atg ata aga tgg $\operatorname{tgc} \operatorname{tgg} a$ & $3-4$ & 114 \\
\hline & & & R: atg gag ttc gat gca aac gtc & & \\
\hline \multirow[t]{2}{*}{$L P L$} & Lipoprotein lipase & NM_001075120 & F: act gtg get gag agc gag aac & $7-8$ & 98 \\
\hline & & & R: tct cca ata tcc acc tcc gtg ta & & \\
\hline \multirow[t]{2}{*}{ PPARA } & $\begin{array}{l}\text { Peroxisome proliferator-activated } \\
\text { receptor alpha }\end{array}$ & NM_001034036.1 & F: agt gec ttt cag ttg gga tgt c & $2-3$ & 125 \\
\hline & & & R: cgc ggt ttc gga atc ttc ta & & \\
\hline \multirow[t]{2}{*}{ PPARG } & $\begin{array}{l}\text { Peroxisome proliferator-activated } \\
\text { receptor gamma }\end{array}$ & NM_181024 & F: tgt ctc ata atg cca tca ggt ttg & $4-5$ & 66 \\
\hline & & & R: tct ccg cta aca gct tct cct t & & \\
\hline \multirow[t]{2}{*}{$S C D$} & Stearoyl-CoA desaturase & NM_173959 & F: cca tca acc ccc gag aga at & $5-6$ & 76 \\
\hline & & & R: aag gtg tgg tgg tag ttg tgg aa & & \\
\hline \multirow[t]{2}{*}{ SREBF1 } & $\begin{array}{l}\text { Sterol regulatory element binding } \\
\text { transcription factor } 1\end{array}$ & NM_001113302 & F: agc ctg gca atg tgt gag aag & $13-14$ & 115 \\
\hline & & & R: caa gga gca ggt cac aca gga & & \\
\hline \multirow[t]{2}{*}{$P P I B^{3}$} & Peptidylprolyl isomerase B & NM_174152 & F: tcc gtc ttc ttc ctg ctg ttg & $1-2$ & 98 \\
\hline & & & R: cca att cgc agg tca aag tac & & \\
\hline \multirow[t]{2}{*}{$R P L P O^{4}$} & Ribosomal protein P0 & NM_001012682 & F: gca ttc ccg ctt cct gg & $5-6$ & 109 \\
\hline & & & R: gcg ctt gta ccc att gat ga & & \\
\hline
\end{tabular}

${ }^{5}$ Published in [69].

${ }^{1}$ Entrez Gene, National Center for Biotechnology Information (NCBI).

${ }^{2} \mathrm{~F}$ : forward primer and R: reverse primer.

${ }^{3}$ Housekeeping gene for muscle.

${ }^{4}$ Housekeeping gene for subcutaneous adipose tissue.

accuracy of primer pairs was also evaluated by the presence of a unique peak during the dissociation step at the end of RT-qPCR. A set of five candidate housekeeping genes (HKG) was evaluated using geNorm and NormFinder, following the procedures described by Vandesompele et al. [67] and Andersen et al. [68], respectively. Therefore, target gene expression levels were normalised against the expression levels of the HKG, ribosomal protein large P0 (RPLPO) and peptidylprolyl isomerase $\mathrm{B}(P P I B)$ for SAT and muscle, respectively.

\section{Real time quantitative polymerase chain reaction}

The RT-qPCR was performed with the StepOne Plus ${ }^{\text {tax }}$ Real-Time PCR System, using the Power SYBR ${ }^{\circ}$ Green master mix (both Applied Biosystems, Foster City, CA, USA). Reaction mixes of $6.25 \mu \mathrm{L}$ Power SYBR Green master mix (Applied Biosystems, Foster City, CA, USA), $1 \mu \mathrm{L}$ of forward and reverse primers $(160 \mathrm{nM})$ and $1 \mu \mathrm{L}$ of diluted cDNA (1:10) template were pipetted into
MicroAmp ${ }^{\text {Tx }}$ optical 96-Well reaction plates and sealed with optical caps (Applied Biosystems, Foster City, CA, USA). After an initial denaturation at $95^{\circ} \mathrm{C}$ for $10 \mathrm{~min}$, a thermocycling program of $15 \mathrm{~s}$ at $95^{\circ} \mathrm{C}, 60 \mathrm{~s}$ at $60^{\circ} \mathrm{C}$ and $15 \mathrm{~s}$ at $95^{\circ} \mathrm{C}$ was applied (40 cycles). Total fluorescence data and dynamic well factors were continuously collected to generate background-subtracted amplification curves (StepOne ${ }^{\mathrm{Tn}}$ Software v2.2.2, Applied Biosystems, Foster City, CA, USA). PCR analysis of cDNA samples was performed in duplicate, using no-transcription and no-template samples as controls. The specificity of the PCR amplification was confirmed by melting curve analysis and agarose gel electrophoresis of PCR products.

\section{Data processing}

The PCR efficiency was calculated for each primer set using the StepOnePlus PCR System software (Applied Biosystems), by amplifying 5-fold serial dilutions of pooled cDNA and run in triplicate. The efficiency curves 
were used to assess accuracy, linearity and efficiency of the PCR reaction. Efficiency $(\mathrm{E})$ was calculated as $\mathrm{E}[\%]=$ $(10-1 /$ slope of standard curve -1$) \times 100$. All primer sets exhibited an efficiency ranged between 85 and $110 \%$ and correlation coefficients were higher than 0.990 .

The relative expression (RE) levels were calculated as a variation of the Livak method [70], corrected for variation in amplification efficiency $\left(\mathrm{E}=10^{-1 / \text { slope }}\right)$, as shown in Equation 1.

$$
R E=E_{\text {endogenous }}(C T, \text { edogenous }) / E_{\text {target }}(C T, \text { target })
$$

\section{Statistical analysis}

Statistical analyses were carried out with the Statistical Analysis Systems software package, version 9.2, (SAS Institute, Cary, NC, USA). All statistical analyses were performed based on a $2 \times 2$ factorial arrangement of breed (Alentejana and Barrosã purebreds), diet (high and low silage diets) and their respective interaction. The variances were tested for heteroscedasticity and, for most parameters, variance was found to be heterogeneous. Therefore, subsequent data analysis was performed in order to account for heterogeneous variance. The general Satterthwaite approximation was computed in a mixed-effects regression model (PROC MIXED), with breed, diet and their interaction as fixed effects.

The slaughter weight, total lipids content in the muscle and SAT were tested as covariates, but only total lipids was retained. Whenever the use of a covariate was necessary, the structure of the covariate model was determined according to the procedures described by Milliken \& Johnson [71], ranging from a simple slope model to individual slopes for each diet $\times$ breed combinations. Given that significant differences in covariate ranges were intrinsically associated to each breed, each variable was adjusted and compared with the mean covariate value of each breed [71]. When significant effects were detected, least square means (LSMEANS) were determined using the LSMEANS option, with no correction for multiple comparisons. Differences were declared significant at $P<0.05$ and tendencies discussed at $P<0.10$.

Pearson correlation coefficients were calculated using the CORR procedure of SAS. Whenever necessary, adjusted variables to the intramuscular fat or the amount of subcutaneous adipose tissue in the leg joint were used to compute Pearson correlations, for the muscle and SAT samples respectively.

The relationships between cellularity and fatty acid composition in both depots were assessed by the principal component analysis (PCA), using the PRINCOMP procedure of SAS. The PCA was applied to a data set of 78 samples and 17 variables to reduce the dimensionality of the data set and to describe the variability of data. The PCA was used to examine the relationship between the fatty acid composition and relative gene expression levels, enabling not only plots of the relationship between the variables but also attempting to explain those relationships. The analysis was based on the correlation matrix and the principal components which explained at least $5 \%$ for the total variance and had eigenvalues were greater than one were retained.

\section{Abbreviations \\ ACACA: Acetyl-CoA carboxylase alpha; BCFA: Branched chain fatty acids: CRAT: Carnitine O-acetyltransferase; CLA: Conjugated linoleic acid; FABP4: Fatty acid binding protein 4; FAME: Fatty acid methyl esters; HKG: Housekeeping gene; HS: High silage; LL: Longissimus lumborum; LPL: Lipoprotein lipase; LS: Low silage; MUFA: Monounsaturated fatty acids; PPARA: Peroxisome proliferator-activated receptor alpha; PPARG: Peroxisome proliferator-activated receptor gamma; PPIB: Peptidylprolyl isomerase B; PUFA: Polyunsaturated fatty acids; RPLPO: Ribosomal protein PO; SAT: Subcutaneous adipose tissue; SFA: Saturated fatty acids; SCD: Stearoyl- CoA desaturase; SREBF1: Sterol regulatory element binding transcription factor 1; TAG: Triacylglycerols; TFA: Trans fatty acids.}

\section{Competing interests}

There are no conflicts of interest.

\section{Authors' contributions}

ASHC and VMRP performed the tissue sampling and laboratory work. ASHC was responsible for the statistical analysis. ASHC, VMRP, CMGAF and JAMP were responsible for interpretation of the results and preparation of the manuscript. JAMP was responsible for the design of the study. All authors read and approved the findings of the study.

\section{Acknowledgments}

Financial support from Fundação para a Ciência e a Tecnologia grant (PTDC) CVT/2006/66114) and individual fellowships to A.S.H. Costa (SFRH/BD/2009/ 61068) and V.M.R. Pires (SFRH/BPD/2009/64347) are acknowledged. The authors would like to thank the abattoir staff for their cooperation in meat sampling, Susana Alves (L-INIA-REQUIMTE) for fatty acid analysis and Elisabete Silva for kindly providing primers for the PPIB gene.

Received: 9 October 2012 Accepted: 12 June 2013

Published: 17 June 2013

\section{References}

1. Hocquette JF, Chatellier V: Prospects for the European beef sector over the next 30 years. Anim Front 2011, 25:20-28.

2. Scollan N, Hocquette JF, Nuernberg K, Dannenberger D, Richardson I, Moloney A: Innovations in beef production systems that enhance the nutritional and health value of beef lipids and their relationship with meat quality. Meat Sci 2006, 74:17-33.

3. Pickworth $\mathrm{CL}$, Loerch SC, Velleman SG, Pate JL, Poole DH, Fluharty FL: Adipogenic differentiation state-specific gene expression as related to bovine carcass adiposity. J Anim Sci 2011, 89:355-366.

4. Hiller B, Hocquette JF, Cassar-Malek I, Nuernberg G, Nuernberg K: Dietary $n-3$ PUFA affect lipid metabolism and tissue function-related genes in bovine muscle. Br J Nutr 2012, 108:858-863.

5. Roh S, Hishikawa D, Hong Y-H, Sasaki S: Control of adipogenesis in ruminants. Anim Sci J 2006, 77:472-477.

6. Mannen $\mathrm{H}$ : Identification and utilization of genes associated with beef qualities. Anim Sci J 2011, 82:1-7.

7. Taniguchi M, Guan LL, Zhang B, Dodson MV, Okine E, Moore SS: Gene expression patterns of bovine perimuscular preadipocytes during adipogenesis. Biochem Bioph Res Co 2008, 366:346-351. 
8. Fernyhough ME, Helterline DL, Vierck JL, Hausman GJ, Hill RA, Dodson MV: Dedifferentiation of mature adipocytes to form adipofibroblasts: more than just a possibility. Adipocytes 2005, 1:17-24.

9. Wang $\mathrm{YH}$, Byrne KA, Reverter A, Harper GS, Taniguchi M, McWilliam SM, Mannen $H$, Oyama K, Lehnert S: Transcriptional profiling of skeletal muscle tissue from two breeds of cattle. Mamm Genome 2005, 16:201-210.

10. Zhang Q, Lee HG, Han JA, Kim EB, Kang SK, Yin J, Baik M, Shen Y, Kim SH, Seo KS, Choi YJ: Differentially expressed proteins during fat accumulation in bovine skeletal muscle. Meat Sci 2010, 86:814-820.

11. Lee SH, Gondro C, van der Werf J, Kim NK, Lim DJ, Park EW, Oh SJ, Gibson JP, Thompson JM: Use of a bovine genome array to identify new biological pathways for beef marbling in Hanwoo (Korean Cattle). BMC Genomics 2010, 11:623.

12. Lehnert S, Reverter A, Byrne KA, Wang Y, Nattrass GS, Hudson NJ, PL G w: Gene expression studies of developing bovine longissimus muscle from two different beef cattle breeds. BMC Dev Biol 2007, 7:95.

13. Aldai N, Najera Al, Dugan ME, Celaya R, Osoro K: Characterization of intramuscular, intermuscular and subcutaneous adipose tissues in yearling bulls of different genetic groups. Meat Sci 2007, 76:682-691.

14. Wood JD, Enser M, Fisher AV, Nute GR, Sheard PR, Richardson RI, Hughes SI, Whittington FM: Fat deposition, fatty acid composition and meat quality: a review. Meat Sci 2008, 78:343-358.

15. Widman P, Nuernberg K, Kuehn C, Weikard R: Association of an ACSL1 gene variant with polyunsaturated fatty acids in bovine skeletal muscle. BMC Genet 2011, 12:96.

16. Pavan E, Duckett SK: Corn oil or corn grain supplementation to steers grazing endophyte-free tall fescue. I. Effects on in vivo digestibility, performance, and carcass quality. J Anim Sci 2008, 86:3215-3223.

17. Hoashi S, Hinenoya T, Tanaka A, Ohsaki H, Sasaki S, Taniguchi M, Oyama K, Mukai $\mathrm{F}$, Mannen $\mathrm{H}$ : Association between fatty acid compositions and genotypes of FABP4 and LXR-alpha in Japanese Black cattle. BMC Genet 2008, 9:84

18. Beja-Pereira A, Alexandrino P, Bessa I, Carretero Y, Dunner S, Ferrand N, Jordana J, Laloe D, Moazami-Goudarzi K, Sanchez A, Cañon J: Genetic characterization of Southwestern European bovine breeds: a historical and biogeographical reassessment with a set of 16 microsatellites. $J$ Hered 2003, 94:243-250.

19. Costa P, Lemos JP, Lopes PA, Alfaia CM, Costa ASH, Bessa RJB, Prates JAM: Effect of low- and high-forage diets on meat quality and fatty acid composition of Alentejana and Barrosã beef breeds. Animal 2012, 6:1187-1197.

20. Wang $\mathrm{YH}$, Bower NI, Reverter A, Tan SH, De Jager N, Wang R, Macwilliam SM, Cafe LM, Greenwood PL, Lenhert SA: Gene expression patterns during intramuscular fat development in cattle. J Anim Sci 2009, 87:119-130.

21. Albrecht $E$, Gotoh T, Ebara F, Xu JX, Viergutz T, Nüernberg G, Maak S, Wegner J: Cellular conditions for intramuscular fat deposition in Japanese Black and Holstein steers. Meat Sci 2011, 89:13-20.

22. Taniguchi M, Mannen H, Oyama K, Shimakura Y, Oka A, Watanabe H, Kojima T, Komatsu M, Harper GS, Tsuji S: Differences in stearoyl-CoA desaturase mRNA levels between Japanese Black and Holstein cattle. Livest Prod SCi 2004, 87:215-220.

23. Medina-Gomez G, Gray SL, Yetukuri L, Shimomura K, Virtue S, Campbell M, Curtis RK, Jimenez-Linan M, Blount M, Yeo GSH, Lopez M, Seppänen-Laakso T, Ashcroft FM, Orešič M, Vidal-Puig A: PPAR gamma 2 prevents lipotoxicity by controlling adipose tissue expandability and peripheral lipid metabolism. PLoS Genet 2007, 3:e64.

24. Gregoire FM, Smas CM, Sul HS: Understanding adipocyte differentiation. Physiol Rev 1998, 78:783-880.

25. Harper GS, Pethick DW: How might marbling begin? Aust J Exp Agr 2004, 44:653-662.

26. Briggs MR, Yokoyama C, Wang X, Brown MS, Goldstein JL: Nuclear protein that binds sterol regulatory element of low density lipoprotein receptor promoter. I. Identification of the protein and delineation of its target nucleotide sequence. J Biol Chem 1993, 268:14490-14496.

27. Brown MS, Goldstein JL: The SREBP pathway: regulation of cholesterol metabolism by proteolysis of a membrane-bound transcription factor. Cell 1997, 89:331-340.

28. Worgall TS, Sturley SL, Seo T, Osborne TF, Deckelbaum RJ: Polyunsaturated fatty acids decrease expression of promoters with sterol regulatory element-binding protein. J Biol Chem 1998, 273:25537-25540.
29. Graugnard DE, Berger LL, Faulkner DB, Loor JJ: High-starch diets induce precocious adipogenic gene network up-regulation in longissimus lumborum of early-weaned Angus cattle. Brit J Nutr 2010, 103:953-963.

30. Kim JB, Wright HM, Wright M, Spiegelman BM: ADD1/SREBP1 activates PPARgamma through the production of endogenous ligand. Proc Nat Acad Sci USA 1998, 95:4333-4337.

31. Costa ASH, Lopes PA, Estevão M, Martins SV, Alves SP, Pissarra H, Correia JJ, Pinho M, Fontes CMGA, Prates JAM: Contrasting cellularity and fatty acid composition in fat depots from Alentejana and Barrosã bovine breeds fed high and how forage diets. Int J Biol Sci 2012, 8:214-227.

32. Sekiya M, Yahagi N, Matsuzaka T, Takeuchi $Y$, Nakagawa $Y$, Takahashi $H$ Okazaki H, lizuka Y, Ohashi K, Gotoda T, Ishibashi S, Nagai R, Yamazaki T, Kadowaki T, Yamada N, Osuga J, Shimano H: SREBP-1-independent regulation of lipogenic gene expression in adipocytes. J Lipid Res 2007, 48:1581-1591

33. Yang R, Castriota G, Chen Y, Cleary MA, Ellsworth K, Shin MK, Tran J-L, Vogt TF, Wu M, Xu S, Yang X, Zhang BB, Berger JP, Quresh SA: RNAi-mediated germline knockdown of FABP4 increases body weight but does not improve the deranged nutrient metabolism of diet-induced obese mice. Int J Obesity 2011, 35:217-225.

34. Shen WJ, Bernlohr K, Sridhar DA, Bernlohr DA, Kraemer FB: Interaction of rat hormone-sensitive lipase with adipocyte lipid-binding protein. $P$ Natl Acad Sci USA 1999, 96:5528-5532.

35. Damcott CM, Moffett SP, Feingold E, Barmada MM, Marshall JA, Hamman $R F$, Ferrell RE: Genetic variation in fatty acid-binding protein-4 and peroxisome proliferator-activated receptor gamma interactively influence insulin sensitivity and body composition in males. Metabolism 2004, 53:303-309.

36. Cho S, Park TS, Yoon D, Cheong HS, Namgoong S, Park BL, Lee HW, Han CS, Kim EM, Cheong I-C, Kim H, Shin HD: Identification of genetic polymorphisms in FABP3 and FABP4 and putative association with back fat depth in Wagyu $\times$ Limousin F2 crosses. Anim Genet 2008, 37:29-34.

37. Jurie C, Cassar-Malek I, Bonnet M, Leroux C, Bauchart D, Boulesteix P, Pethick DW, Hocquette JF: Adipocyte fatty acid-binding protein and mitochondrial enzyme activities in muscles as relevant indicators of marbling in cattle. J Anim Sci 2007, 85:2660-2669.

38. Michal JJ, Zhang ZW, Gaskins CT, Jiang Z: The bovine fatty acid binding protein 4 gene is significantly associated with marbling and subcutaneous fat depth in Wagyu $\times$ Limousin F2 crosses. Anim Genet 2006, 37:400-402.

39. Laliotis GP, Bizelis I, Rogdakis E: Comparative approach of the de novo fatty acid synthesis (lipogenesis) between ruminant and non ruminant mammalian species: from biochemical level to the main regulatory lipogenic genes. Curr Genomics 2010, 11:168-183.

40. McGarry JD, Woeltje KF, Kuwajima M, Foster DW: Regulation of ketogenesis and the renaissance of carnitine palmitoyltransferase. Diabetes Metab Rev 1989, 5:271-284.

41. Joseph SJ, Robbins KR, Pavan E, Pratt SL, Duckett SK, Rekaya R: Effect of diet supplementation on the expression of bovine genes associated with fatty acid synthesis and metabolism. Bioinform Biol Insights 2010, 4:19-31.

42. Chilliard Y, Gagliostro G, Fléchet J, Lefaivre J, Sebastian I: Duodenal rapeseed oil infusion in early and midlactation cows. 5 . Milk fatty acids and adipose tissue lipogenic activities. J Dairy Sci 1991, 74:1844-1854.

43. Underwood KR, Tong J, Zhu MJ, Shen QW, Means WJ, Ford SP, Paisley SI, Hess BW, Du M: Relationship between kinase phosphorylation, muscle fiber typing, and glycogen accumulation in longissimus muscle of beef cattle with high and low intramuscular fat. J Agr and Food Chem 2007, 55:9698-9703.

44. Daniel CTR, Wynn RJ, Salter AM, Buttery PJ: Differing effects of forage and concentrate diets on the oleic acid and conjugated linoleic acid content of sheep tissues: The role of stearoyl-CoA desaturase. J Anim Sci 2004, 82:747-758

45. Ward RE, Woodward B, Otter N, Doran O: Relationship between the expression of key lipogenic enzymes, fatty acid composition, and intramuscular fat content of Limousin and Aberdeen Angus cattle. Livest Sci 2010, 127:22-29.

46. Chung KY, Lunt DK, Kawachi H, Yano H, Smith SB: Lipogenesis and stearoyl-CoA desaturase gene expression and enzyme activity in adipose tissue of short- and long-fed Angus and Wagyu steers fed corn- or haybased diets. J Anim Sci 2007, 85:380-387. 
47. Dance LJE, Matthews KR, Doran O: Effect of breed on fatty acid composition and stearoyl-CoA desaturase protein expression in the Semimembranosus muscle and subcutaneous adipose tissue of cattle. Livest Sci 2009, 125:291-297.

48. Duckett SK, Pratt SL, Pavan E: Corn oil or corn grain supplementation to steers grazing endophyte-free tall fescue. II. Effects on subcutaneous fatty acid content and lipogenic gene expression. J Anim Sci 2009, 87:1120-1128.

49. Bartoň $L$, Bureš $D$, Kott $T$, Řehák D: Effect of sex and age on bovine muscle and adipose fatty acid composition and stearoyl-CoA desaturase mRNA expression. Meat Sci 2011, 89:444-450.

50. Nakamura MT, Nara TY: Essential fatty acid synthesis and its regulation in mammals. Prostag Leukotr Ess 2003, 68:145-150.

51. Ntambi JM, Miyazaki M: Regulation of stearoyl-CoA desaturases and role in metabolism. Prog Lipid Res 2004, 43:91-104.

52. Barbier O, Torra IP, Duguay Y, Blanquart C, Fruchart JC, Glineur C, Staels B: Pleiotropic actions of peroxisome proliferator-activated receptors in lipid metabolism and atherosclerosis. Arterioscler Thromb Vasc Biol 2002, 22:717-726.

53. Guillou H, Martin P, Jan S, D'Andrea S, Roulet A, Catheline D, Rioux V, Pineau T, Legrand P: Comparative Effect of Fenofibrate on Hepatic Desaturases in Wild-Type and Peroxisome Proliferator-Activated Receptor a-Deficient Mice. Lipids 2002, 37:981-989.

54. Jogl G, Hsiao YS, Tong L: Structure and function of carnitine acyltransferases. Ann NY Acad Sci 2006, 1033:17-29.

55. Calabrese V, Stella AMG, Calvani M, Butterfield DA: Acetylcarnitine and cellular stress response: roles in nutritional redox homeostasis and regulation of longevity genes. J Nutr Biochem 2006, 17:73-88.

56. Smith SB, Crouse JD: Relative contributions of acetate, lactate and glucose to lipogenesis in bovine intramuscular and subcutaneous adipose tissue. J Nutr 1984, 114:792-800.

57. Schoonmaker JP, Fluharty FL, Loerch SC: Effect of source and amount of energy and rate of growth in the growing phase on adipocyte cellularity and lipogenic enzyme activity in the intramuscular and subcutaneous fat depots of Holstein steers. J Anim Sci 2004, 82:137-148.

58. Dodson MV, Hausman GJ, Guan LL, Min D, Rasmussen TP, Poulos SP, Mir P, Bergen WG, Fernyhough ME, McFarland DC, Rhoads RP, Soret B, Reecy JM, Velleman SG, Jiang Z: Lipid metabolism, adipocyte depot physiology and utilization of meat an- imals as experimental models for metabolic research. Int J Bio Sci 2010, 6:691-699.

59. Eguinoa P, Brocklehurst S, Arana A, Mendizabal JA, Vernon RG, Purroy A: Lipogenic enzyme activities in different adipose depots of Pirenaican and Holstein bulls and heifers taking into account adipocyte size. J Anim Sci 2003, 81:432-440

60. Martins AP, Lopes PA, Costa ASH, Martins SV, Santos NC, Prates JAM, Moura TF, Soveral G: Differential mesenteric fat deposition in bovines fed on silage or concentrate is independent of glycerol membrane permeability. Animal 2011, 5:1949-1956.

61. Costa ASH, Costa P, Bessa RJB, Lemos JPC, Simões JA, Santos-Silva J, Fontes CMGA, Prates JA: Carcass fat partitioning and meat quality of Alentejana and Barrosã young bulls fed high or low maize silage diets. Meat Sci 2013, 93:405-412.

62. Folch J, Lees M, Stanley GHS: A simple method for the isolation and purification of total lipides from animal tissues. J Biol Chem 1957, 226:497-509.

63. Carlson LA: Extraction of lipids from human whole serum and lipoproteins and from rat liver tissue with methylene chloride-methanol: A comparison with extraction with chloroform-methanol. Clin Chim Acta 1985, 149:89-93.

64. Raes K, Smet SD, Demeyer D: Effect of double-muscling in Belgian Blue young bulls on the intramuscular fatty acid composition with emphasis on conjugated linoleic acid and polyunsaturated fatty acids. Anim Sci 2001, 73:253-260.

65. Bessa RJB, Alves SP, Jerónimo E, Alfaia CM, Prates JAM, Santos-Silva J: Effect of lipid supplements on ruminal biohydrogenation intermediates and muscle fatty acids in lambs. Eur J Lipid Sci Technol 2007, 109:868-878.

66. Rego O, Rosa H, Regalo S, Alves S, Alfaia C, Prates J, Vouzela C, Bessa R: Seasonal changes of CLA isomers and other fatty acids of milk fat from grazing dairy herds in the Azores. J Agr Food Chem 2008, 88:1855-1859.
67. Vandesompele J, De Preter K, Pattyn F, Poppe B, Van Roy N, De Paepe A, Speleman F: Accurate normalization of real-time quantitative RT-PCR data by geometric averaging of multiple internal control genes. Genome Biol 2002, 3:7.

68. Andersen $\mathrm{CL}$, Jensen $\mathrm{L}$, Orntoft TF: Normalization of real-time quantitative reverse transcription-PCR data: A model-based variance estimation approach to identify genes suited for normalization, applied to bladder and colon cancer data sets. Cancer Res 2004, 64:5245-5250.

69. Costa ASH, Silva MP, Alfaia CPM, Pires VMR, Fontes CMGA, Bessa RJB, Prates JAM: Genetic Background and Diet Impact Beef Fatty Acid Composition and Stearoyl-CoA Desaturase mRNA Expression. Lipids 2013, 48:369-381.

70. Livak KJ, Schmittgen TD: Analysis of relative gene expression data using real-time quantitative PCR and the 2(-Delta C(T)) Method. Methods 2001, 25:402-408.

71. Milliken GA, Johnson DE: Analysis of Messy Data, Volume III: Analysis of Covariance. London: Chapman and Hall/CRC; 2002.

doi:10.1186/1746-6148-9-118

Cite this article as: da Costa et al: Expression of genes controlling fat deposition in two genetically diverse beef cattle breeds fed high or low silage diets. BMC Veterinary Research 2013 9:118.

\section{Submit your next manuscript to BioMed Central and take full advantage of:}

- Convenient online submission

- Thorough peer review

- No space constraints or color figure charges

- Immediate publication on acceptance

- Inclusion in PubMed, CAS, Scopus and Google Scholar

- Research which is freely available for redistribution 